rozumiana, jeśli nie zostanie wzmocniona i uzupełniona należytym opisem i interpretacją faktów, z uwzględnieniem przeszłości tej bliższej, jak i dalszej.

Reasumując, należy podkreślić wartość poznawczą i aplikacyjną recenzowanej książki, która stanowi cenną pozycję na krajowym rynku wydawniczym. Winna znaleźć też zastosowanie w dydaktyce akademickiej, zwłaszcza na studiach politologicznych i historycznych oraz związanych z szeroko rozumianym bezpieczeństwem, jako niezwykle istotne źródło dociekania kondycji współczesnej cywilizacji.

Dariusz SKALSKI

Wałcz

DOI : $10.14746 / \mathrm{pp} .2014 .19 .2 .19$

\title{
Konstytucja Księstwa Liechtensteinu, tł. z jęz. niem. Radosław Grabowski, wstęp Sabina Grabowska; Wydawnictwo Sejmowe, Warszawa 2013, ss. 108.
}

Wydawnictwo Sejmowe od lat - w ramach serii wydawniczej „Konstytucje” - sukcesywnie przybliża rodzimym konstytucjonalistom, politologom i pasjonatom teksty ustaw zasadniczych różnych państw. Na szczególne uznanie zasługuje upowszechnianie wiedzy o konstytucjach krajów, które rzadko bywają obiektem zainteresowania polskich badaczy. Przykładem takiej pracy jest wydana w 2013 roku książka pt. Konstytucja Księstwa Liechtensteinu. Składa się ona z trzech części: wstępu, tłumaczenia tekstu ustawy zasadniczej oraz czterech aneksów, a jej uzupełnieniem jest spis podstawowej literatury.

Wstęp autorstwa Sabiny Grabowskiej zawiera najbardziej elementarne informacje dotyczące geografii oraz uwarunkowań społeczno-demograficznych tego niewielkiego kraju. Zasadnicza jego część poświęcona jest prezentacji historii księstwa ze zwróceniem szczególnej uwagi na kształtowanie się ustroju od chwili powstania państwa w obecnym kształcie aż po czasy współczesne. Odrębny fragment wstępu zajmuje przedstawienie generalnej rewizji postanowień konstytucji, która miała miejsce w 2003 roku. Rozważania zamyka syntetyczna charakterystyka systemu partyjnego oraz zasad sukcesji tronu, czyli materii o fundamentalnym znaczeniu w każdej monarchii.

Kluczową ze względu na temat, a zarazem najbardziej obszerną częścią książki jest thumaczenie konstytucji księstwa z języka niemieckiego dokonane przez Radosława Grabowskiego. Zajmuje ono ponad połowę opracowania, w związku z czym na podkreślenie zasługuje czytelny układ tekstu z wyraźnie wyodrębnionymi rozdziałami ustawy zasadniczej.

Wartościowym dopełnieniem pracy są cztery aneksy. Zawierają one odpowiednio: wykaz wszystkich nowelizacji konstytucji w latach 1929-2011 (aneks nr 1), tabele prezentujące wyniki wyborów parlamentarnych (odsetek głosów oddanych na poszczególne listy i liczbę zdobytych mandatów) w okresie 1986-2009 (aneks nr 2), zestawienie książąt Liechtensteinu od początku powstania państwa (aneks nr 3) oraz szefów rządu od czasu przyjęcia obecnej ustawy zasadniczej (aneks nr 4).

Książkę zamyka spis podstawowej literatury (co istotne - obejmujący również prace wydane w języku polskim) oraz wykaz liechtensteinowskich stron internetowych obejmujący zarówno portale o tematyce ogólnej, jak i serwisy bardziej specjalistyczne (np. bazę krajowych aktów prawnych). Pozwala to osobom bliżej zainteresowanym na dalsze samodzielne pogłębianie wiedzy o kraju.

Zasługi Wydawnictwa Sejmowego w upowszechnianiu wiedzy o rozwiązaniach ustrojowych funkcjonujących w tzw. państwach karłowatych, są trudne do przecenienia. Konstytucja księstwa Liechtensteinu jest już kolejną - po analogicznych książkach dotyczących Watykanu 
i Monako ${ }^{1}$ - publikacją, która porusza tego rodzaju problematykę. Oprócz tych prac-wydanych w ramach serii „Konstytucje” - nakładem tego samego wydawnictwa ukazały się książki poświęcone systemom konstytucyjnym mikropaństw oraz ich parlamentom².

Niewątpliwie największym plusem recenzowanej publikacji jest zawarcie w niej tłumaczenia ustawy zasadniczej księstwa i to w najbardziej aktualnej wersji - uwzględniającej wszystkie dotychczasowe (tj. przyjęte do 2013 r.) zmiany. Nie jest to co prawda pierwszy polski przekład konstytucji Liechtensteinu - pierwszeństwo na tym polu przysługuje autorom książki Konstytucja Księstwa Liechtensteinu: naród, państwo, polityka, którzy zresztą pokusili się również o umieszczenie oryginalnej wersji językowej - niemniej jednak jakość obecnego tłumaczenia jest zauważalnie wyższa. Niewątpliwym walorem pracy jest syntetyczny wstęp zarysowujący dzieje księstwa i ewolucję ustrojową do czasów obecnych, a zarazem przedstawiający życie polityczne kraju. Warto odnotować, że autorzy szczególną uwagę poświęcili reformie ustrojowej z 2003 roku, a także przedstawieniu zasad sukcesji tronu, czyli materii wykraczającej poza obszar regulowany prawem państwowym. Na podkreślenie zasługuje również atrakcyjna dla czytelnika forma książki: czytelny układ poszczególnych rozdziałów, poręczne rozmiary oraz usztywniona oprawa.

Mimo skromnej objętości Konstytucja księstwa Liechtensteinu jest niewątpliwie opracowaniem wartościowym, co jednak nie znaczy, że wolnym od mankamentów i braków. Największy niedosyt pozostawia niezamieszczenie mapy księstwa. Byłaby ona naturalnym i wartościowym uzupełnieniem, zwłaszcza biorąc pod uwagę wzmiankę (s. 7) o specyficznej - wynikającej z feudalnej spuścizny - strukturze terytorialnej kraju.

Niewątpliwą słabością wpływającą na ogólną ocenę publikacji są błędy, których niestety nie ustrzegli się autorzy pracy. Dotyczy to zarówno nieścisłości merytorycznych, jak i potknięć czy niezręczności językowych. Do tej pierwszej grupy z pewnością zaliczyć można stwierdzenie, że „bezpieczeństwo zewnętrzne kraju zapewnia Szwajcaria” (s. 8) ${ }^{3}$. Jakkolwiek Berno faktycznie reprezentuje interesy księstwa na arenie międzynarodowej, szwajcarska straż graniczna zapewnia ochronę granicy z Austrią, a policja - będąca jedyną państwową formacją uzbrojoną Liechtensteinu - blisko współpracuje ze swoimi szwajcarskimi odpowiednikami ${ }^{4}$, to współpraca ta nie ma wymiaru militarnego i nie obejmuje sfery obronności (Snyder, 2010, s. 34). Wśród nieścisłości wypada wymienić także: pomylenie cenzusu dochodowego z majątkowym (s. 11), którego osiągnięcie - w myśl konstytucji z 1818 roku - dawało chłopom prawo do wyboru swoich przedstawicieli stanowych; informację sugerującą że tworzenie formacji policyjnych jest dozwolone jedynie w razie zagrożenia państwa (s. 18) ${ }^{5}$, czy wzmianka o istnieniu w latach II wojny światowej Naro-

${ }^{1}$ Konstytucja Watykanu, tłum. F. Longchamps de Bérier, M. Zubik, wstęp: F. Longchamps de Bérier, M. Zubik, Warszawa 2008; Konstytucja Księstwa Monako, tłum. K. Wojtyczek, A. Wojtyczek-Bonnand, wstęp: K. Wojtyczek, Warszawa 2012. Oprócz tego, przedmiotem analogicznych opracowań były konstytucje innych niewielkich państw: Islandii, Malty, Cypru i Luksemburga.

${ }^{2}$ Dotyczy to dwóch prac P. Osóbki - Systemy konstytucyjne Andory, Liechtensteinu, Monako, San Marino, Warszawa 2008 oraz Systemy konstytucyjne państw Oceanil, Warszawa 2012.

${ }^{3}$ Akapit dotyczący bezpieczeństwa jest zreszta - podobnie jak niektóre zdania wstępu - niemal dosłownym zapożyczeniem z Wikipedii - por. http://pl.wikipedia.org/w/index.php?title=Liechtenstein\&oldid=24793469 [wersja z 1.01.2011 - dostęp: 10.07.2013].

${ }^{4}$ Wspólpraca ta zresztą nie tyle jest efektem porozumień na szczeblu władz obu państw, co jest inicjatywą opartą na porozumieniu (Ostschweizer Polizeikonkordat) policji Liechtensteinu z analogicznymi formacjami sześciu kantonów i dwóch miast wschodniej Szwajcarii - http://www.ostpol.ch/ 5503/5557.html [dostęp: 10.07.2013].

${ }^{5} \mathrm{~W}$ rzeczywistości konstytucja (art. 44) dopuszcza istnienie formacji do pelnienia służby policyjnej w każdym czasie, natomiast w sytuacji zagrożenia państwa zobowiązuje do obrony kraju każdego, kto nie ukończył 60 lat i jest zdolny do noszenia broni. 
dowosocjalistycznej Partii Liechtensteinu'. Niezbyt fortunny - ze względu na domniemane poddanie w wątpliwość kulturowej odrębności Austriaków i Szwajcarów - jest również passus mówiący o „Niemcach ze Szwajcarii i Austrii” jako przedstawicielach „ludności obcej” w księstwie (s. 8).

Drugą grupę błędów stanowią lapsusy językowe, które - chociaż nie wpływają w istotnym stopniu na merytoryczną ocenę książki - nie wystawiają najlepszego świadectwa pracy redaktora. Dobrym przykładem jest zdanie: „przepisy prawa zwyczajowego zastąpiły austriackie kodeksy, cywilny i karny" (s. 10), z którego trudno wywnioskować, co właściwie zostało zastąpione. Do tej samej kategorii zaliczyć wypada również rozbieżności dotyczące okresu panowania księcia Jana I - o ile w aneksie nr 3 (s. 102) wskazano daty prawidłowe (1805-1836), o tyle w tekście (s. 10) jako rok zakończenia rządów błędnie podano 1846. Listę lapsusów i truizmów uzupełniają wzmianki o przeprowadzeniu „rozdawnictwa ziemi” (s. 10), ,skierowaniu niezadowolenia ku Austriakom” (s. 15), czy też stwierdzenia w rodzaju: „mniej niż 2/3 ludności podaje się za rodowitych mieszkańców Liechtensteinu” (s. 8), „ewolucja systemu konstytucyjnego jest cechą charakterystyczną Liechtensteinu” czy też ,podstawowym trybem zmiany ustawy zasadniczej tego państwa jest zmiana częściowa" (s. 25).

Odrębnym mankamentem są niedoskonałości przekładu, które niekiedy wynikają z nadmiernej dosłowności. Najlepszym przykładem jest art. 30, którego thumaczenie brzmi „Uzyskanie i utratę praw obywatelskich określa ustawa", czenie mniej dosłowne w rodzaju: „Ustawa określa zasady nabywania i utraty praw obywatelskich". Zastrzeżenia można mieć również do sposobu tłumaczenia nazw niektórych funkcji. Skoro bowiem członkowie rządu zostali przetłumaczeni dosłownie jako ,radcy rządowi” (niem. Regierungsräten), to konsekwencja nakazywałaby podobne potraktowanie szefa rządu. W tym przypadkujednak określenie Regierungschef zostało przetłumaczone jako ,premier”.

W niektórych przypadkach uwadze tłumacza umknęły drobne niuanse, czego egzemplifikacją może być przekład art. 78 ust. 4 konstytucji. W polskim tłumaczeniu pominięto fakt, że tworzenie instytucji prawa publicznego realizujących pod nadzorem rządu zadania gospodarcze, socjalne i kulturalne wymaga przepisów rangi ustawowej.

Podobnie jak w przypadku wstępu, tak i w odniesieniu do przekładu konstytucji można mieć zastrzeżenia do pracy korektora, czego ilustracją jest art. 95 ust. 1 („Wymiar sprawiedliwości jest sprawowany [...] przez prawnie umocowanych sędziów do tego sędziów..." s. 77) oraz przypis 117 (s. 79), w którym zastąpiono użyty w oryginalnym tekście wyraz Rechtpflegern wyrazem Rechtspflege.

Konstytucja Księstwa Liechtensteinu jest niewątpliwie interesującą publikacją, która kontynuuje tradycje wydawcy upowszechniania wiedzy na temat mniej znanych systemów politycznych. Koncentracja na zagadnieniach rzeczywiście istotnych oraz czytelny układ są mocnymi stronami pracy. Niestety, pozytywny obraz całości naruszają niezręczności i błędy oraz pozostawiająca wiele do życzenia korekta tekstu. Mankamenty te nie przekreślają co prawda wartości merytorycznej opracowania, ale nie ulega wątpliwości, że oczekiwania formułowane w stosunku do tak prestiżowej i zasłużonej instytucji, jak Wydawnictwo Sejmowe mogą i powinny być większe.

Marek ŚMIGASIEWICZ

Warszawa

${ }^{6} \mathrm{~W}$ rzeczywistości ugrupowanie nazistowskie w księstwie działało pod nazwą Volksdeutsche Bewegung in Liechtenstein - np. http://www.e-archiv.li/print/3366.pdf [dostęp: 10.07.2013].

${ }^{7}$ W oryginale: Über Erwerb und Verlust des Staatsbürgerrechtes bestimmen die Gesetze. 